\title{
Pleurotus tuber-regium inclusion in diet ameliorates dyslipidaemia in obese-type 2 diabetic rats
}

\author{
Akindele Oluwatosin Adeyi ${ }^{1 *}$ (D) Folasade Ajoke Adams $^{2}$ and Clementina Oyinkansola Adenipekun²
}

\begin{abstract}
Background: Pleurotus tuber-regium (P.T) is an edible mushroom with abundant polysaccharides that has been used in traditional medicine to treat diabetes mellitus. This study investigated the hypoglycaemic potential and ameliorative activity of Pleurotus tuber-regium incorporated diet on diabetes induced dyslipidaemia.

Materials and methods: Thirty five (35) adult male wistar rats were randomly assigned to seven groups; Normal control, diabetic control, obese control, obese diabetic control, 10\% PT, 20\% PT, and Drug control. Type II DM was induced by placing the animals on high fat diet for a period of 10 weeks and a single intraperitoneal injection of streptozotocin $(50 \mathrm{mg} / \mathrm{kg} / \mathrm{BW})$. P. T was incorporated into the feed and given to the animals for two weeks daily after the confirmation of diabetes.

Results: Treatment of the obese diabetic rats with P. T supplemented diet caused a decrease in the blood glucose level compared to the control groups. Increased organo-somatic ratio of the kidney and heart were markedly $(p<$ 0.05 ) reduced following treatment (20\% P.T). Furthermore, cholesterol, triglycerides, LDL-C and VLDL-C levels were reduced due to treatment accompanied by increased HDL-C in the liver. Histological evaluation of the liver, kidney, heart, and pancreas of the P. T treated groups were comparable to normal.
\end{abstract}

Conclusion: Incorporation of $P$. tuber-regium in diets could be effective in reversing dyslipidaemia in obese diabetic patients.

Keywords: Pleurotus tuber-regium, Type 2 diabetes mellitus, Dyslipidaemia, Diet, Obesity, Streptozotocin

\section{Introduction}

In the recent times, obesity and diabetes have been on the increase around the world due to widespread changes in nutritional habits, increased sedentary lifestyles, and lack of physical activities. Diabetes mellitus is a group of metabolic disorders with the hallmark of chronic hyperglycaemic resulting from insufficient secretion of insulin or action [1]. The most common type of diabetes is Type 2 diabetes (T2D) accounting for about $90 \%$ of cases [2] and it is characterized by inadequate insulin release and inaction of released insulin on targeted

\footnotetext{
*Correspondence: delegenius@yahoo.com

${ }^{1}$ Animal Physiology Unit, Department of Zoology, University of Ibadan, Ibadan, Nigeria

Full list of author information is available at the end of the article
}

organs [3]. Studies have shown that most T2D patients are often obese, insulin resistant, and prone to pancreatic $\beta$-cell dysfunction [4]. Hence, obesity and poor adipocyte differentiation are important contributors to incidence of dyslipidaemia in T2D subjects.

According to International Federation of Diabetes, the prevalence of diabetes worldwide is increasing with over 151 million people diagnosed to be diabetic in 2000, 194 million in 2003, 246 million in 2006, 285 million in 2010, and 415million in 2015 [5]. Therefore, the continuous increase in the incidence of diabetes will pose socioeconomic effect on many countries particularly, the less developed African countries, where allopathic antidiabetic drugs are relatively expensive [6,7] Research findings have shown that the prevalence rate of diabetes 
in Africa is similar or higher than what is obtained in some developed countries with over 4 million in 1980 to 25 million in 2014, and 60 million in 2020 [8, 9]. Alarmingly, Nigeria being the most populous country in Africa, has been reported as having the Africa's highest burden of diabetes with over 3.9 million people among persons aged 20-79 years [10]. Currently, the estimated prevalence now stands at 18 million [8].

Medicinal mushrooms have been identified as remarkable therapeutic agents in traditional folk medicines and important as popular culinary products all over the world [11, 12]. Mushroom is a fleshy, spore bearing fruiting body, typically produced above ground on soil or on its food source [13]. They are widely distributed all over the world, with some growing naturally in Nigeria during the early and late rainy seasons [14]. They are usually found in forests, grasslands, damp rotten logs etc. [15]. Often, mushrooms are composed of vitamins [16], proteins with essential amino acids, phosphorus, iron, [17], and a mushroom - derived secondary metabolite like phenolic, polypeptides, terpenes, steroids and vitamins which are of great value in human diet [18-20]. Many fungal species are known to possess medicinal values and some are already being used for such purposes [21].

Information available showed that many mushrooms are useful feed supplements for promotion of health and for prevention or treatment of certain diseases of the respiratory, circulatory and digestive system in humans [22]. They have been acknowledged for their antioxidant, antibacterial, anti-viral, anti-inflammatory, antitumor and cytotoxic activities, and also serves as nutraceuticals [23-25]. Furthermore, their immunomodulating, hypoglycaemic, anti-hypercholesterolaemia, and blood pressure preventing ability has been reported [26, 27]. Mushrooms such as Agaricus spp, Cordyceps sinensis, Coprinus comatus, Ganoderma lucidum, Inonotus obliquus, Phellinus linteus, and Pleurotus spp, have been reported to have hypoglycaemic effects [28]. Pleurotus tuber- regium is an edible mushroom which produces edible sclerotium, this is the vegetative part of the mushroom on which its fruiting body grows [29]. It is used in African traditional health care, in preparations for the treatment of childhood malnutrition, colds, fever, headache, inflammation and skin diseases [30, 31]. Its antifungal [32], antibacterial activities [33], and ability to bioremediate crude oil polluted soils [34], degrade xenobiotic pollutants [35] as well as its potential to substitute soybean in feeds for fingerlings [36] have been reported.

In a recent study, Onuekwuzu et al [37] confirmed that flavonoid and sitosterol aqueous extract of Pleurotus tuber-regium sclerotium had a hypoglycaemic effect and also improved lipid profile and atherogenic induces in alloxan induced diabetic rabbits. Hui-yu et al, [38] using polysaccharides extracted from three different culture strains of Pleurotus tuber-regium concluded that its polysaccharides had an antihyperglycaemic property which treats oxidative stress in diabetic rats. Its polysaccharides also attenuate the obese-diabetes induced adverse effect through the maintenance of a stable fatty acid composition thereby reverting obesity and hyperlipidaemia [39]. These studies have been on the aqueous extract from sclerotium and polysaccharides extracted from the culture of Pleurotus tuber-regium. This shows that little is known about the dietary inclusion of the fruiting bodies of Pleurotus tuber-regium. However, Ijeh et al., [40] reported that the dietary inclusion of Pleurotus tuber-regium fruiting bodies at level $5 \%$ and $10 \%$ level had no adverse effects on the vital organs of an albino mouse but indicated that higher percentage is required to achieve a hypolipidaemic effect. This proposes that the dietary inclusion of Pleurotus tuber-regium fruiting body have no deleterious effect and creates a need for further investigation on its dietary incorporation since the said mushroom has many bioactive compounds such as tannins, saponins, alkaloids, oligosaccharides, flavonoid, protein, fibre and several minerals. This study is therefore aimed at investigating the ameliorative potential of the Pleurotus tuber-regium incorporated diet on diabetes induced dyslipidaemia in type 2 DM rat model.

\section{Materials and methods Collection of sample}

Samples of fresh Pleurotus tuber-regium sclerotia were bought from Ojoo Market, Ibadan. The sclerotium were identified by Prof. Clementina O. Adenipekun; a mushroom biotechnologist of the Department of Botany University of Ibadan, Oyo state Nigeria.

\section{Cultivation of Pleurotus tuber-regium}

The sclerotium was washed several times with distilled water, soaked for thirty minutes in water. Some were placed in a perforated soil packed bucket at shallow depths while the remaining was kept in bottle. After 1428 days, mature fruit bodies were harvested and airdried and milled using a blender. A portion was removed for chemical analyses while the rest was used for the feeding studies.

\section{Phytochemical screening of Pleurotus tuber-regium}

Qualitative evaluation of alkaloids, flavonoids, saponins, tannins, steroids, anthraquinones, terpenoids, and cardiac glycosides contents of Pleurotus tuber-regium dry sample was done according to the methods described by Tyler and Herbalgram, [41]; Harborne et al., [42]. Quantitative measurement of saponin was quantified as described by Brunner [43], while the flavonoid and alkaloid 
content was estimated according to the method of Harborne [42].

\section{Proximate analysis of Pleurotus tuber-regium and standard diet}

Moisture content was determined by oven-drying the samples at $105^{\circ} \mathrm{C}$ until constant weight was attained. Crude protein content was estimated on each sample as $\mathrm{N} \times 6.25$, where $\mathrm{N}$ was the total nitrogen content; total carbon and nitrogen contents were determined by combustion on previously freeze-dried and pulverized samples using an elemental analyzer (Thermo Scientific Flash EA 1112. Crude fat content was determined by extraction under reflux with petroleum ether $\left(40^{\circ} \mathrm{C}-60^{\circ}\right.$ $\mathrm{C}$ boiling range) for $6 \mathrm{~h}$. Crude fibre was determined by adding $3 \mathrm{~g}$ of the dried and fat free sample to $200 \mathrm{~mL}$ of $1.25 \% \mathrm{H}_{2} \mathrm{SO}_{4}$ in a beaker. The contents of the beaker were boiled for $30 \mathrm{~min}$ with the supplementation of water; contents were filtered giving 2-3 washings with hot water $(150 \mathrm{~mL})$ until it was acid free. The residue was transferred to a beaker and $200 \mathrm{~mL}$ of $1.25 \% \mathrm{NaOH}$ were added into it. The same process was repeated until it is alkali free. The residue was carefully transferred to a tared crucible, oven dried at $100^{\circ} \mathrm{C}$ for $3-4 \mathrm{~h}$ until constant weight was obtained. The contents were heated on oxidizing (blue) flame until the smoke ceased to come out of the sample. Then the sample was placed in a muffle furnace at $550^{\circ} \mathrm{C}$ for $4 \mathrm{~h}$ until a grey ash was obtained, then cooled in a desiccator and weighed [44]. The difference in weight was recorded as crude fibre and it was calculated by using the formula:

Crude fibre \% = Loss of weight after ignition (g).

Weight of the sample (g).

Ash content was estimated as the difference in mass before and after incinerating oven-dried samples for $24 \mathrm{~h}$ at $525^{\circ} \mathrm{C}$ in a muffle furnace.

Carbohydrate $(\mathrm{CHO})$ content was calculated by difference i.e. \% $\mathrm{CHO}=100$-(Sum of the percentages of moisture, ash, fat, and protein).

\section{Experimental animals, diet, induction, and design Experimental animals}

Wistar strain male albino rats $(n=35)$ aged 8 weeks (weighing $120 \pm 20 \mathrm{~g}$ ) were obtained from the Animal house unit of the Department of Physiology, College of Medicine, University of Ibadan, Oyo state, Nigeria. After acclimatization for two weeks, all rats had access to high-fat diet and water except the normal control and diabetic control that were fed on the standard diet and the animals were housed in groups. All methods are performed in accordance with the relevant guidelines and regulations of the ARRIVE ethical guidelines and approved by animal care and use of research ethics committee (UI-ACUREC) University of Ibadan, Nigeria.

\section{Diet composition}

Standard diet: The super starter feed was fed to the seven groups during the two weeks acclimatization stage. This is the feed composition according to Chikun feed Nigeria.

High fat diet: The super starter feed was milled and mixed with $5 \mathrm{~kg}$ molten lard in a mixer and oven dried. It was later pelletized, dried and fed to the animals for a period of 10 weeks.

Mushroom diet: The mushrooms were air dried, milled into powder form and mixed with the super starter feed to obtain a $10 \%$ and $20 \%$ mushroom feed in pelletized form (Table 1). The mushroom diet was air dried to reduce moisture.10\% and 20\% Pleurotus tuberregium diet were used for this study because of the low dry mass of the mushroom after drying and to ensure its palatability.

\section{Induction of experimental diabetes using streptozotocin}

After two weeks of acclimatization and ten weeks of feeding on high fat diet, rats were fasted overnight before an intraperitoneal injection of streptozotocin (STZ, Sigma, USA). The STZ solution was freshly prepared in $0.1 \mathrm{M}$ citrate buffer ( $\mathrm{pH} 4.5$ ) and $50 \mathrm{mg} / \mathrm{kg}$ bodyweight (bw) was injected in a volume of $0.2 \mathrm{ml}$.Diabetes was confirmed by stable hyperglycaemia of more than 200 $\mathrm{mg} / \mathrm{dL} 72 \mathrm{~h}$ after induction by checking blood glucose from the tail of rats using the Accu-check active glucometer (Roche, Germany). The combined actions of high-fat diet plus STZ injections in this study are projected to increase the obesity levels, and simultaneously maintain the hyperglycaemia.

\section{Experimental design}

The animals were randomised into seven (7) groups of five $(n=5)$ animals each and housed in plastic cages (Table 2).

\section{Feed intake}

The feed intake (FI) in each group during the two (2) weeks treatment was calculated by summing up the Feed intake for the each week (week1 and 2) divided by number of rats (g/week).

Feed intake $(\mathrm{g} /$ week $)=$ Weekly food intake/No. of rats

\section{Administration of Standard Drugs}

$2 \mathrm{mg} / \mathrm{kg}$ of Glibenclamide and $10 \mathrm{mg} / \mathrm{kg}$ of Atenonol were administered orally via $2 \mathrm{ml}$ syringe with the aid of an oral cannula after dissolving them in their respective solvent. $2 \mathrm{mg} / \mathrm{kg}$ of Glibenclamide was dissolved in 10\% dimethyl sulfoxide (DMSO) and $10 \mathrm{mg} / \mathrm{kg}$ of Atenonol was dissolved in water. 
Table 1 Composition of the diets used in this study

\begin{tabular}{llll}
\hline Constituents & Standard Diet & High fat Diet & Mushroom Diet \\
\hline Crude protein (min) & $11.0 \%$ & $11.0 \%$ & $11.0 \%$ \\
Crude fat (min) & $4.0 \%$ & $4.0 \%$ & $4.0 \%$ \\
Crude fibre (max) & $5.0 \%$ & $5.0 \%$ & $5.0 \%$ \\
Calcium (min) & $1.0 \%$ & $1.0 \%$ & $1.0 \%$ \\
Phosphorus (min) & $0.47 \%$ & $0.47 \%$ & $0.47 \%$ \\
Lysine (min) & $1.15 \%$ & $1.15 \%$ & $1.15 \%$ \\
Methionine (min) & $0.5 \%$ & $0.5 \%$ & $0.5 \%$ \\
Metabothable energy (Kcal/kg & 2900 & 2900 & 2900 \\
Lard & - & $20 \%$ & - \\
Mushroom & - & - & $10 \%, 20 \%$
\end{tabular}

The standard diet composition is according to Chikun feed, Olam Company, Nigeria

\section{Periodic weighing of the rats}

The body weights of the rats were measured three times a week, this was done before and after obesity induction, after diabetes induction, and during treatment.

\section{Animal sacrifice and tissue collection}

The animals were treated humanely and were euthanatized after the last day of treatment (14th day) according to the guides by Rowett [45]. Blood was collected via the retro-orbital plexus. The liver, Pancreas, kidney and heart of each rat were collected and stored depending on the analysis to be done.

Organosomatic indices, blood chemistry, lipid profile and histology

\section{Organosomatic indices}

The ratio of the weight of the liver, kidney, heart and pancreas was calculated separately according to Ali (2001) with the formula.

Organosomatic index $=$ Organ weight $(\mathrm{g}) \times 100 /$ Rat body weight (g).

\section{Fasting blood glucose determination}

The blood glucose concentration was determined using a digital glucometer (Accu-check ${ }^{\bullet}$ sensor, Roche diagnostic, Mannheim, Germany).

\section{Haematological studies}

Haematological parameters were analysed using an automated haematology analyser sysmex KX-21 N (Sysmex Corporation, Kohe, Japan).

\section{Estimation of Haemoglobin concentration}

The haemoglobin concentration was measured by cyanmethaemoglobin colorimeter method Cheesbrough [46].

\section{Determination of packed cell volume}

The packed cell volume (PCV) was determined by using the micro haematocrit reader in which the $75 \times 16 \mathrm{~mm}$ capillary tubes was filled with blood and centrifuged for 5 min Cheesbrough, [46].

\section{Estimation of white blood cell (WBC) count}

The total white blood cell count was estimated by visual count method [46].

\section{Differential WBC count/cell morphology}

The Leishmann staining method of Cheesbrough [46] was used for the analysis of the differential count and cell morphology. Dried slide was viewed under oil immersion which was fixed at $\times 100$ objectives and various cells as well as morphological characters was observed, counted and recorded.

Table 2 Experimental design, diet and drug administered

\begin{tabular}{ll}
\hline Groups & Administration \\
\hline Diabetic control & Standard diet+ STZ \\
Obese diabetic control & HFD + STZ \\
$10 \%$ Pleurotus tuber-regium (P.T) & HFD + STZ+ 10\%P.T \\
$20 \%$ Pleurotus tuber-regium (P.T) & HFD + STZ + 20\%P.T \\
Drug control (Standard drugs) & HFD + STZ+ 10 mg/kg of Glibenclamide and Atenonol \\
Obese control & HFD + water \\
Normal control & Standard diet+ water \\
\hline
\end{tabular}

STZ- Streptozotocin, HFD- High Fat Diet, P.T- (Pleurotus tuber-regium) 


\section{Estimation of red blood cell (RBC) count}

Estimation of red blood cell count was carried out using the method by Chessbrough [46]. $0.02 \mathrm{ml}$ of EDTA anticoagulated blood was mixed with $4 \mathrm{ml}$ Turks solution in a plain cuvette, $0.01 \mathrm{ml}$ of the resultant mixture was loaded on the counting chamber, covered and allowed to settle for 2 mins before it was placed under the microscope at $\times 10$ objective. The red cell present in the 4 corners and central $1 \mathrm{~mm} 2$ of the microscope was counted, recorded and the total $\mathrm{RBC}$ was deducted by calculations.

\section{Determination of hematological indices}

Haematological indices were estimated according to the formula described by Cheesbrough [46].

\section{Estimation of mean cell Haemoglobin (MCH)}

The mean cell haemoglobin was estimated using a formula which was reported by Cheesbrough (2004). It was calculated by dividing the value of the haemoglobin concentration by the value of red blood cell count.

\section{Estimation of mean cell Haemoglobin concentration (MCHC)}

The mean cell haemoglobin concentration was estimated using a formula which was reported by Cheesbrough [46]. It was calculated by dividing value of the haemoglobin concentration by the value of packed cell volume.

\section{Estimation of mean cell volume (MCV)}

The mean cell volume was estimated using a formula which was reported by Cheesbrough [46]. It was calculated by the dividing the value of the packed cell volume by the value of red blood cell and then multiplied by the factor of ten.

\section{Estimation of plasma lipid profiles}

Total cholesterol, HDL-cholesterol, and triglyceride was assayed enzymatically with Randox test kits (Randox Laboratories, England) by Friedewald, et al., [47].

\section{Histological studies}

The heart, liver, pancreas and kidney were preserved in $10 \%$ formalin in plain bottle for histological analysis. The organs were passed through increasing concentration of ethanol $(70 \%, 80 \%, 90 \%$ and $100 \%)$ one hour after each other for removal of water from the tissues in the organs. The dehydrated organs were cleaned in three changes of xylene and also infused in three changes of molten wax. The organs were embedded in molten wax which later solidified. Each block was mounted on the microtome, sectioned at $5 \mu$, viewed under a transmission electron microscope and photographed by photomicrography.

\section{Statistical analysis}

All data was represented as the mean $\pm \mathrm{SD}$, to evaluate the differences among groups studied, data was analysed using a one-way analysis of variance (ANOVA), P-values of less than 0.05 was considered significant. Mean values were separated using Duncan Multiple Range Test (DMRT). Graphs were plotted using Graph pad Prism Software 8 .

\section{Results}

Phytochemical constituents of Pleurotus tuber-regium

The results of the phytochemical constituents of Pleurotus tuber-regium show the different type of constituents and the amounts present (Table 2 and Table 3). Alkaloid (0.60\%), flavonoid (7.23\%), and saponins (1.53\%) are present considerably, while tannins, anthraquinones and terpenoids are present in trace amounts, but Cardiac glycoside was not detected (Table 3).

\section{Proximate composition of Pleurotus tuber-regium- supplemented and the super starter feed}

Proximate analysis of Pleurotus tuber-regium shows that it has a high carbohydrate content (49.02\%), slightly lowered than that of the Control feed $(55.20 \%)$. The protein content of the Pleurotus tuber-regium (27.12\%) was higher than the Control feed (23.3\%). The ash content and crude fat content of control feed was higher when compared to the mushroom. Pleurotus tuber-regium has a higher moisture content, and crude fibre when compared to the control feed (Table 4).

\section{Feed intake of the animals}

Evaluation of the feed intake by Wistar rats fed during the two weeks treatment as seen in Table 5 showed that the group fed with $10 \%$ Pleurotus tuber-regium has the higher feed intake of $238 \pm 3.4$ when compared to $20 \%$ Pleurotus tuber-regium group $215 \pm 4.7$. The drug control group has a lowest feed intake of $115 \pm 2.8$ when compared to all the other groups.

The diabetic control group and obese diabetic control have a low feed intake of $117 \pm 2.5$ and $138 \pm 2.9$ when

Table 3 Qualitative and quantitative phytochemical screening of Pleurotus tuber-regium

\begin{tabular}{|c|c|c|c|c|c|c|c|c|}
\hline Phytochemical & Alkaloids & Flavonoids & Saponins & Tannins & Steroids & Anthraquinones & Terpenoids & Cardiac glycoside \\
\hline Qualitative analysis & ++ & ++++ & +++ & + & + & + & + & - \\
\hline Quantitative analysis (\%) & $0.60 \pm 0.05$ & $7.23 \pm 0.03$ & $1.53 \pm 0.03$ & $0.13 \pm 0.00$ & $0.1 \pm 0.01$ & $0.11 \pm 0.00$ & $0.01 \pm 0.01$ & \\
\hline
\end{tabular}

Data were expressed as mean \pm SD $(n=3)+$ : present in minute quantity,,+++++ and ++++: present in abundance, - : absent, 
Table 4 Proximate composition of Pleurotus tuber-regium and Standard diet (Control feed) (g/100 g)

\begin{tabular}{lllllll}
\hline & $\begin{array}{l}\text { Moisture content } \\
(\%)\end{array}$ & $\begin{array}{l}\text { Crude protein } \\
(\%)\end{array}$ & $\begin{array}{l}\text { Crude fat } \\
(\%)\end{array}$ & $\begin{array}{l}\text { Crude fibre } \\
\text { (\%) }\end{array}$ & $\begin{array}{l}\text { Ash content } \\
(\%)\end{array}$ & $\begin{array}{l}\text { Carbohydrate } \\
\text { (\%) }\end{array}$ \\
\hline Pleurotus tuber-regium & $16.91 \pm 0.03$ & $27.12 \pm 0.02$ & $0.69 \pm 0.01$ & $17.58 \pm 0.02$ & $6.23 \pm 0.02$ & $49.02 \pm 0.03$ \\
Standard diet & $9.26 \pm 0.1$ & $23.3 \pm 0.1$ & $5.03 \pm 0.1$ & $5.0 \pm 0.0$ & $7.2 \pm 0.1$ & $55.20 \pm 0.1$ \\
\hline
\end{tabular}

Data were taken in triplicates. Values are expressed as mean \pm SD.

compared to P. T groups, obese control group and Normal control group.

\section{The mean body weight of the treated and untreated diabetic rats}

The body weight of the groups fed with the high fat diet increased progressively when compared to the groups fed with the standard diet (Super starter feed). After diabetes induction, the entire diabetic group had reduced weight when compared to normal control group and obese control group. The diabetic control group as well as the obese- diabetic group decreased in body weight throughout the experimental period as shown in Fig. 1.

\section{Pleurotus tuber-regium normalises the blood glucose level of streptozotocin -induced diabetic rats}

The blood glucose concentration before induction of diabetes ranged between 69.33 to $85.67 \mathrm{mg} / \mathrm{dL}$ (Fig. 2). The streptozotocin administered groups had their blood glucose increased remarkably between a range of 192 to $352.7 \mathrm{mg} / \mathrm{dL}$ when compared to the normal control group and obese control group. After treatment, there was a marked reduction in the blood glucose level of 10\% Pleurotus tuber-regium group and 20\% Pleurotus tuber-regium group when compared to normal control group and obese group.

\section{The effect of Pleurotus tuber-regium diets on the organs of the diabetic rats}

The organosomatic ratio of the liver, kidney, heart and pancreas are shown in (Table 6).

There is a significant increase in the liver somatic index of the diabetic control group and obese diabetic control group when compared to the normal control as well as the mushroom supplemented diet treatment groups. The diabetic control and obese diabetic control group have an increased kidney somatic index which differs significantly from all the other groups. There is a decrease in the heart somatic index of $10 \%$ Pleurotus tuber-regium group and 20\% Pleurotus tuber-regium group when compared to the other experimental groups.
There is no significant difference between pancreas somatic indexes of all the experimental groups.

\section{The effect of Pleurotus tuber-regium treatment on the blood haematology of the diabetic rat}

There was no significant difference in the white blood cells, platelet, Mean Corpuscular Volume, Mean Corpuscular Haemoglobin of all the experimental groups. The packed cell volume (PCV) of obese group, obese diabetic control group and Drug control group differs significantly from normal control group and diabetic control group, and there is an increase in the PCV of diabetic control and $10 \%$ mushroom supplemented diet. There is a marked decrease in the haemoglobin level of the obese diabetic control group when compared to the normal control group, diabetic control group and 10\% mushroom supplemented diet. There is a significant $(p<0.05)$ increase in the red blood cells (RBC) of $10 \%$ Pleurotus tuber-regium group when compared to the obese group, obese diabetic control group, 20\% Pleurotus tuberregium group and Drug control group. There is an increase in the blood platelet of 10\% Pleurotus tuberregium group when compared to the other groups. Mean Corpuscular Haemoglobin Concentration of the obese group differs significantly from the diabetic control group, but there is no significant difference between Pleurotus tuber-regium treatment groups and the normal control group. The differential leucocytes count of the rat shows no significant difference in the lymphocytes, and eosinophil of all the experimental groups. However, there is a significant decrease in the Neutrophils of Pleurotus tuber-regium treatment groups when compared to normal control group (Tables 7 and 8).

\section{Effects of Pleurotus tuber-regium on plasma and liver lipid profile of diabetic rats}

Levels of TC, TG, LDL and VLDL were highest in the diabetic and obese control rats (Table 9). However, treatment with 10 and $20 \% \mathrm{P}$. T significantly reduced plasma TC, TG, LDL and VLDL of treated rats when compared with diabetic and obese control rats. Whereas,

Table 5 Weekly feed intake of the rats during treatment of diabetic rats

\begin{tabular}{|c|c|c|c|c|c|c|c|}
\hline & Diabetic control & Obese diabetic control & 10\%P.T & $20 \%$ P.T & Drug control & Obese control & Normal control \\
\hline Week 1 & $110 \pm 5.0$ & $133 \pm 2.6$ & $208 \pm 7.4$ & $190 \pm 11$ & $104 \pm 6.1$ & $238 \pm 4.9$ & $222 \pm 7.0$ \\
\hline Week 2 & $117 \pm 2.5$ & $138 \pm 2.9$ & $238 \pm 3.4$ & $215 \pm 4.7$ & $115 \pm 2.8$ & $247 \pm 3.3$ & $229 \pm 3.3$ \\
\hline
\end{tabular}

Values are expressed as mean \pm SD 

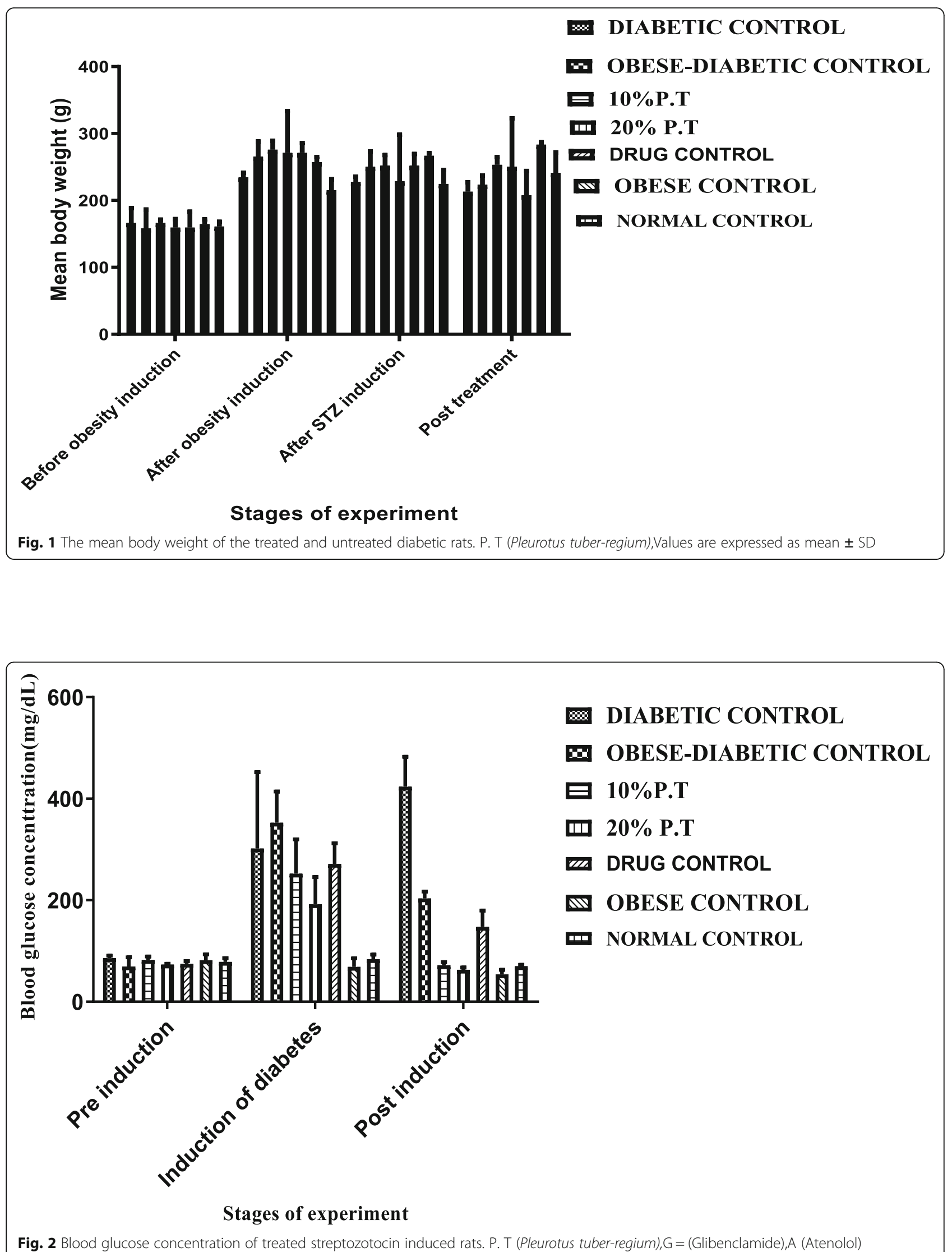
Table 6 Effect of Pleurotus tuber-regium on the organosomatic index of the diabetic rat

\begin{tabular}{lllll}
\hline & Liver & Kidney & Heart & Pancreas \\
\hline Diabetic control & $0.036 \pm 0.01^{\mathrm{bc}}$ & $0.008 \pm 0.001^{\mathrm{b}}$ & $0.003 \pm 0.00^{\mathrm{bc}}$ & $0.002 \pm 0.00^{\mathrm{a}}$ \\
Obese diabetic & $0.039 \pm 0.003^{\mathrm{c}}$ & $0.008 \pm 0.001^{\mathrm{b}}$ & $0.0028 \pm 0.00^{\mathrm{bc}}$ & $0.004 \pm 0.00^{\mathrm{a}}$ \\
10\% P.T & $0.029 \pm 0.003^{\mathrm{a}}$ & $0.005 \pm 0.00^{\mathrm{a}}$ & $0.002 \pm 0.00^{\mathrm{a}}$ & $0.003 \pm 0.00^{\mathrm{a}}$ \\
$\mathbf{2 0 \%}$ P.T & $0.03 \pm 0.00^{\mathrm{abc}}$ & $0.005 \pm 0.00^{\mathrm{a}}$ & $0.002 \pm 0.00^{\mathrm{ab}}$ & $0.004 \pm 0.00^{\mathrm{a}}$ \\
Drug control & $0.031 \pm 0.00^{\mathrm{ab}}$ & $0.006 \pm 0.00^{\mathrm{ab}}$ & $0.003 \pm 0.001^{\mathrm{bc}}$ & $0.001 \pm 0.00^{\mathrm{a}}$ \\
Obese control & $0.031 \pm 0.00^{\mathrm{ab}}$ & $0.004 \pm 0.00^{\mathrm{a}}$ & $0.003 \pm 0.00^{\mathrm{abc}}$ & $0.002 \pm 0.00^{\mathrm{a}}$ \\
Normal control & $0.030 \pm 0.00^{\mathrm{ab}}$ & $0.006 \pm 0.00^{\mathrm{ab}}$ & $0.003 \pm 0.00^{\mathrm{c}}$ & $0.002 \pm 0.00^{\mathrm{a}}$ \\
\hline
\end{tabular}

Values are expressed as mean \pm SD, P. T (Pleurotus tuber-regium), Drug control (Glibenclamide and Atenonol) Mean with the same alphabet within a column are not significantly different at $\mathrm{P}<0.05$

HDL increased significantly in rats treated with 10 and $20 \%$ P. T, while rats treated with the standard control drug also had higher plasma HDL in the obese diabetics, the reductions did not attain any statistical significance. Regardless, the group treated with $20 \%$ P. T reversed the decrease in the plasma TC, TG, and HDL comparable to the normal control (Table 10) (Fig. 3). Similarly, hepatic TC, TG, and HDL decreased markedly in the obese diabetic animals when compared with the normal control (Fig. 4). However, treatment with P. T (20\%) caused an increased TG, TC, and HDL levels. Interestingly, VLDL level in the diabetic, obese diabetic controls decreased significantly compared to the other groups.

Pleurotus tuber-regium incorporated diet ameliorate T2DM - mediated derangement in the histology of the liver

The liver of diabetic control showed prominent portal area caused by fibrous hyperplasia, while liver of the obese diabetic control had centrilobular hepatocellular vacuolar degeneration (Fig. 3). Livers of rats treated with 10\% Pleurotus tuber-regium and 20\% Pleurotus tuberregium) had moderate portal congestion, with a moderate periportal vacuolar degeneration of hepatocytes. Livers of Drug control rats showed mild periportal vacuolar degeneration of hepatocytes. Also obese control had hepatocytes showing vesicles with accentuation of sinusoids with diffuse hepatocellular degeneration (microvesicular) and necrosis. Normal control rats had liver with no visible lesion.

Pleurotus tuber-regium incorporated diet ameliorate T2DM - mediated derangement in the histology of the heart

Heart of diabetic control rats showed severe congestion and haemorrhage into the myofibre interstitium (Fig. 4). Also, heart of obese diabetic control had congestion of the coronary vessels. However, hearts of rats treated with 10\% Pleurotus tuber-regium and 20\% Pleurotus tuber-regium showed no visible leison. Hearts of Drug control rats had severe myofibre degeneration and necrosis with inflammatory cell infiltrates. Obese control rats had multiple foci of myofibre degeneration (loss of striations). Normal control rats showed no visible lesion.

\section{Pleurotus tuber-regium incorporated diet ameliorate T2DM - mediated derangement in the histology of the kidney}

Kidneys of diabetic control showed severe interstitial and glomerular congestion with few foci of severe tubular degeneration and necrosis (Fig. 5). Kidneys of obese diabetic control showed no observable lesion, but with tubules that are ectatic. Kidneys of rats treated with $10 \%$ Pleurotus tuber-regium showed very mild interstitial congestion at the renal cortex, while kidneys of rats treated with $20 \%$ Pleurotus tuber-regium showed few foci of tubular degeneration and necrosis and few tubules

Table 7 Effect of Pleurotus tuber-regium on haematological indices of the diabetic rats

\begin{tabular}{|c|c|c|c|c|c|c|c|c|}
\hline & $\begin{array}{l}\text { PCV } \\
(\%)\end{array}$ & $\begin{array}{l}\text { HB } \\
(g / d l)\end{array}$ & $\begin{array}{l}\text { RBC } \\
\left(\times 10^{6} / \mathrm{mm}^{3}\right)\end{array}$ & $\begin{array}{l}\text { WBC } \\
\left(10^{3} / \mathrm{mm}^{3}\right)\end{array}$ & PLT & $\begin{array}{l}\text { MCV } \\
(f / l)\end{array}$ & $\begin{array}{l}\mathrm{MCH} \\
(\mathrm{pg})\end{array}$ & $\begin{array}{l}\text { MCHC } \\
(\%)\end{array}$ \\
\hline Diabetic control & $56 \pm 2.7^{c}$ & $18.1 \pm 0.7 d$ & $8.6 \pm 0.1 b c$ & $34.00 \pm 953 a$ & $1170 \pm 1300 a$ & $64.52 \pm 2 . a$ & $21.07 \pm 0.6 a$ & $32.28 \pm 0.9 a$ \\
\hline Obese diabetic & $45.3 \pm 1.5^{a}$ & $15.1 \pm 0.6 a$ & $7.5 \pm 0.1 \mathrm{a}$ & $32.33 \pm 127 a$ & $1143 \pm 7095 a$ & $60.73 \pm 1.0 a$ & $20.28 \pm 0.7 \mathrm{a}$ & $33.39 \pm 1.1 \mathrm{ab}$ \\
\hline $10 \%$ P.T & $54.3 \pm 4.0 c$ & $17.7 \pm 1.1 \mathrm{~cd}$ & $8.7 \pm 0.2 c$ & $32.00 \pm 1453 a$ & $1470 \pm 28620 b$ & $62.73 \pm 4.3 a$ & $20.48 \pm 1.2 \mathrm{a}$ & $32.66 \pm 0.4 a b$ \\
\hline $20 \%$ P.T & $48.33 \pm 5.0 a b$ & $16.0 \pm 1.5 \mathrm{ab}$ & $7.99 \pm 0.5 a b$ & $30.50 \pm 1191 a$ & $1170 \pm 6083 a$ & $60.37 \pm 2.4 a$ & $20.04 \pm 0.53 a$ & $33.2 \pm 0.5 a b$ \\
\hline Drug control & $47 \pm 3.61 a$ & $15.6 \pm 1.3 a b$ & $7.8 \pm 0.6 a$ & $34.83 \pm 880.8 a$ & $1223 \pm 4933 a b$ & $60.26 \pm 0.1 a$ & $19.95 \pm 0.15 a$ & $33.11 \pm 0.2 \mathrm{ab}$ \\
\hline Obese control & $46.3 \pm 1.5 a$ & $15.7 \pm 0.5 a b$ & $7.7 \pm 0.4 a$ & $32.33 \pm 425.2 \mathrm{a}$ & $1127 \pm 15950 a$ & $60.21 \pm 1.6 a$ & $20.36 \pm 0.5 a$ & $33.82 \pm 0.2 b$ \\
\hline Normal control & $53 \pm 20 b c$ & $17.3 \pm 0.8 \mathrm{bcd}$ & $8.5 \pm 0.1 b c$ & $34.67 \pm 680.7 a$ & $12,700 \pm 15520 \mathrm{ab}$ & $62.49 \pm 1.9 a$ & $20.43 \pm 0.7 a$ & $32.7 \pm 0.6 \mathrm{ab}$ \\
\hline
\end{tabular}

Results are expressed as mean $\pm S D, n=5$. Mean with the same alphabet within a column are not significantly different at $P<0.05$ using Duncan multiple range test for separation of statistically significant means. P.t (Pleurotus tuber-regium) PCV(Packed cell volume), HB (haemoglobin), RBC (Red blood cel) I, WBC (White blood cell), PLT (Platelet), MCV (Mean Corpuscular Volume), MCH (Mean Corpuscular Haemoglobin), MCHC (Mean Corpuscular Haemoglobin Concentration) 
Table 8 Effect of Pleurotus tuber-regium on differential leucocytes of the diabetic rats

\begin{tabular}{|c|c|c|c|c|}
\hline $\begin{array}{l}\text { Haematological parameters/ } \\
\text { Groups }\end{array}$ & $\begin{array}{l}\text { LYM } \\
\left(10^{3} / \mathrm{mm}^{3}\right)\end{array}$ & $\begin{array}{l}\text { NEUT } \\
\left(10^{3} / \mathrm{mm}^{3}\right)\end{array}$ & $\begin{array}{l}\text { MON } \\
\left(10^{3} / \mathrm{mm}^{3}\right)\end{array}$ & $\begin{array}{l}\text { EOS } \\
\left(10^{3} / \mathrm{mm}^{3}\right)\end{array}$ \\
\hline Diabetic control & $77.33 \pm 3.22^{\mathrm{a}}$ & $19.67 \pm 3.22^{\mathrm{ab}}$ & $2.00 \pm 0.0^{\mathrm{ab}}$ & $1.00 \pm 1.0^{\mathrm{a}}$ \\
\hline Obese diabetic control & $75 \pm 1.73^{\mathrm{a}}$ & $21.67 \pm 1.53^{\mathrm{ab}}$ & $1.00 \pm 1.0^{\mathrm{a}}$ & $2.33 \pm 1.16^{a}$ \\
\hline $10 \%$ P.T & $77.33 \pm 2.3^{\mathrm{a}}$ & $19.00 \pm 2.65^{a}$ & $1.33 \pm 0.58^{a}$ & $2.33 \pm 0.58^{a}$ \\
\hline 20\%P.T & $74 \pm 3.0^{a}$ & $22.67 \pm 4.04^{\mathrm{ab}}$ & $1.67 \pm 0.58^{\mathrm{a}}$ & $1.33 \pm 1.53^{\mathrm{a}}$ \\
\hline Drug control & $76.33 \pm 3.06^{a}$ & $18.67 \pm 3.79^{\mathrm{a}}$ & $3.00 \pm 1.0^{b}$ & $2.00 \pm 0.0^{a}$ \\
\hline Obese control & $75 \pm 1.0^{a}$ & $21.33 \pm 1.53^{\mathrm{ab}}$ & $2.00 \pm 1.0^{\mathrm{ab}}$ & $1.67 \pm 1.16^{\mathrm{a}}$ \\
\hline Normal control & $73 \pm 1.0^{\mathrm{a}}$ & $25.00 \pm 1.73^{b}$ & $1.33 \pm 0.58^{\mathrm{a}}$ & $0.67 \pm 0.58^{a}$ \\
\hline
\end{tabular}

Results are expressed as mean $\pm S D, n=5$. Mean with the same alphabet within a column are not significantly different at $P<0.05$ using Duncan multiple range test for separation of statistoically LYM (Lymphocytes), NEUT (Neutrophils), MON (Monocytes), EOS (Eosinophil); P. T (Pleurotus tuber-regium)

have proteinaceous casts in the lumen. Kidneys of drug control rats had vacuolated glomeurlus and tubular epithelial cells that are normal, while kidney of obese control rats had diffuse coagulation necrosis of tubular epithelial cells. Normal control rats had no visible lesion.

\section{Pleurotus tuber-regium incorporated diet ameliorate T2DM} - mediated derangement in the histology of the pancreas Pancreas of diabetic control rats showed mild diffuse congestion of the periductular and perilobular connective tissue (Fig. 6). Obese diabetic control rats had pancreas with necrosis of acinar cells and inflammation of Islet cells. However, pancreas of rats treated with $10 \%$ Pleurotus tuber-regium and 20\% Pleurotus tuber-regium showed no visible lesions. Also, pancreas of drug control rats showed diffuse pancreatic acini atrophy, and necrosis of Islet cells. Pancreas of obese control rats had swollen and degenerated pancreatic acinar cells with loss of Islet cells. Pancreas of normal control rats showed no visible lesion.

\section{Discussion}

The phytochemical analyses of Pleurotus tuber- regium show the presence of alkaloids, saponins, and flavonoids that have been reported to possess hypoglycaemic and anti-diabetic properties [48]. The presence of high carbohydrate content in its proximate composition indicates the presence of polysaccharides, which have been reported to have antihyperlipidaemic, antihyperglycaemic, and antioxidant properties attributing its effect as reduction in lipid profile and oxidative stress $[38,39]$. In addition, the presence of dietary fibre is of great importance because they are responsible for lowering body mass index which is an obesity indicator [49]. The protein content in the mushroom-supplemented food was higher than that reported by Akindahunsi et al., [50]. According to FAO [51], the protein quality of mushrooms is better than that of most vegetables due to the presence of all the essential amino acids, which agrees with Cheskin et al. [52]. Cheskin also suggested that inclusion of low-density calories, such as the mushroom, into foods in the daily diet in place of foods with higher energy density might be beneficial to the reduction of the prevalence of obesity and overweight in a population. The lower carbohydrate content, higher fibre content and protein content (27.12) when compared to Ijeh et al., [40] can be due to the location and varying soil factor [53].

The obese diabetic rat model mimics the features of type 2 diabetes (T2DM) which was achieved by the combined actions of high-fat diet and streptozotocin injection $[54,55]$. Rats injected with STZ showed an elevated

Table 9 Effect of Pleurotus tuber-regium supplemented diet on the lipid profile in the blood of the rats

\begin{tabular}{|c|c|c|c|c|c|}
\hline $\begin{array}{l}\text { LIPID PROFILE/ } \\
\text { GROUPS }\end{array}$ & $T C$ & $T G$ & $H D L$ & $L D L$ & $V L D L$ \\
\hline A (Normal diet) & $72.56 \pm 2.65^{b}$ & $53.67 \pm 1.53^{b}$ & $39.67 \pm 4.51^{b c}$ & $21.6 \pm 2.60^{a}$ & $7.73 \pm 0.31^{\mathrm{a}}$ \\
\hline$B$ (obese; HFD) & $79.33 \pm 3.28^{c}$ & $55.33 \pm 4.45^{b c}$ & $25.67 \pm 2.21^{\mathrm{a}}$ & $24.64 \pm 3.47^{\mathrm{ab}}$ & $10.06 \pm 1.89^{b}$ \\
\hline C (Diabetic untreated) & $78.33 \pm 4.16^{c}$ & $56.33 \pm 4.51 \mathrm{bc}$ & $27.33 \pm 2.52^{\mathrm{a}}$ & $29.74 \pm 1.01$ bc & $10.27 \pm 0.90^{b}$ \\
\hline$D$ (Obese diabetic untreated) & $81.67 \pm 2.42^{d}$ & $61.67 \pm 2.08^{c}$ & $30.78 \pm 4.44{ }^{a b}$ & $28.33 \pm 1.67^{b}$ & $11.33 \pm 0.42^{b c}$ \\
\hline$E(10 \%$ Pleurotustuber-regium supplemented diet) & $65.33 \pm 4.16^{\mathrm{a}}$ & $46.33 \pm 4.51^{\mathrm{ab}}$ & $37.33 \pm 2.52^{b}$ & $23.73 \pm 1.01^{\mathrm{ab}}$ & $9.47 \pm 1.75^{a b}$ \\
\hline F(20\%Pleurotustuber-regium supplemented diet) & $68.34 \pm 3.46^{\mathrm{ab}}$ & $40.33 \pm 6.43^{\mathrm{a}}$ & $39.67 \pm 4.044^{b c}$ & $22.27 \pm 4.50^{\mathrm{ab}}$ & $9.07 \pm 1.29$ ab \\
\hline G (Atenonol + Glibenclamide) & $61.67 \pm 3.02^{\mathrm{a}}$ & $45.33 \pm 5.51^{\mathrm{ab}}$ & $39.33 \pm 5.03^{b c}$ & $23.27 \pm 2.19^{a b}$ & $9.67 \pm 1.10^{a b}$ \\
\hline
\end{tabular}

Results are expressed as mean $\pm \mathrm{SD}, n=5$. Mean with the same alphabet within a column are not significantly different at $P<0.05$. KEY

TC = Total Cholesterol, TG = Triglyceride, HDL = High Density Lipoprotein, LDL = Low Density Lipoprotein, VLDL = Very Low Density Lipoprotein 


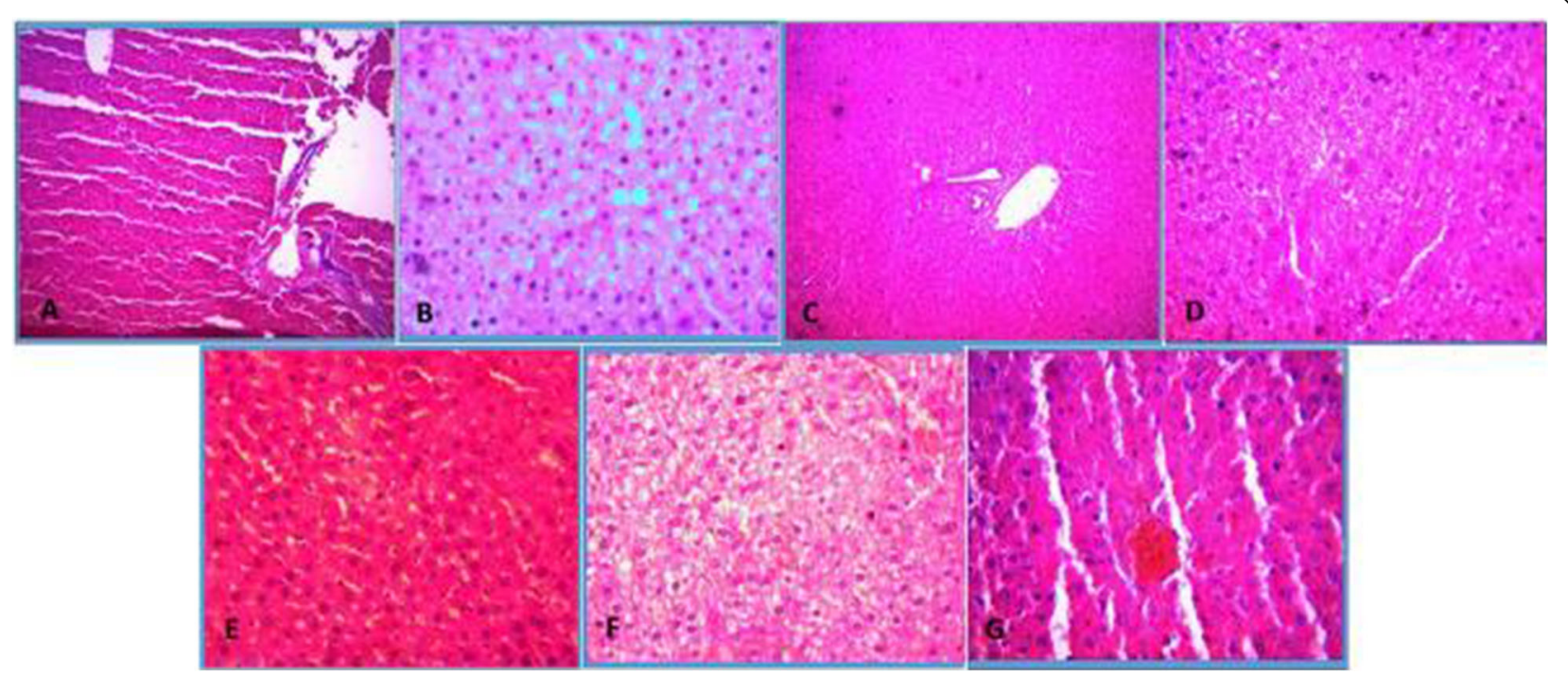

Fig. 3 Photomicrograph slides of rat liver (Hematoxylin and eosin staining, 100x magnification). A: Liver of Diabetic control; B: Liver of Obese diabetic control; C: Liver of Obese diabetic rats treated with 10\% Pleurotus tuber-regium; D: Liver of Obese diabetic rats treated with 20\% Pleurotus tuber-regium; E: Liver of Drug control rats; F: Liver of Obese control rats; G Liver of Normal control rats

blood glucose level, which is indicative of hyperglycaemia. However, treatment of the obese diabetic rats with Pleurotus tuber-regium supplemented diet decreased the blood glucose level when compared to the drug control suggesting its anti-hyperglycaemic activity.

Organosomatic ratio might be used as an index for acute organ damage; including the liver, kidney, spleen, and other visceral [56]. We observed an increase in the hepatic and renal organosomatic ratios in the obese diabetic and diabetic controls. Thomas et al., [57] reported that kidney enlargement might be due to hyperplasia (rapid production of the cell leading to enlarged tissues) and hypertrophy (enlargement of cell components) of the kidney which might be due to inflammation of the organ. Treatment with Pleurotus tuber-regium supplemented diet reduced the kidney size, showing a possible nephropathic effect in the kidneys of diabetic rats. Decrease in the heart somatic index of the Pleurotus tuber-regium supplemented diet treated groups when compared to the

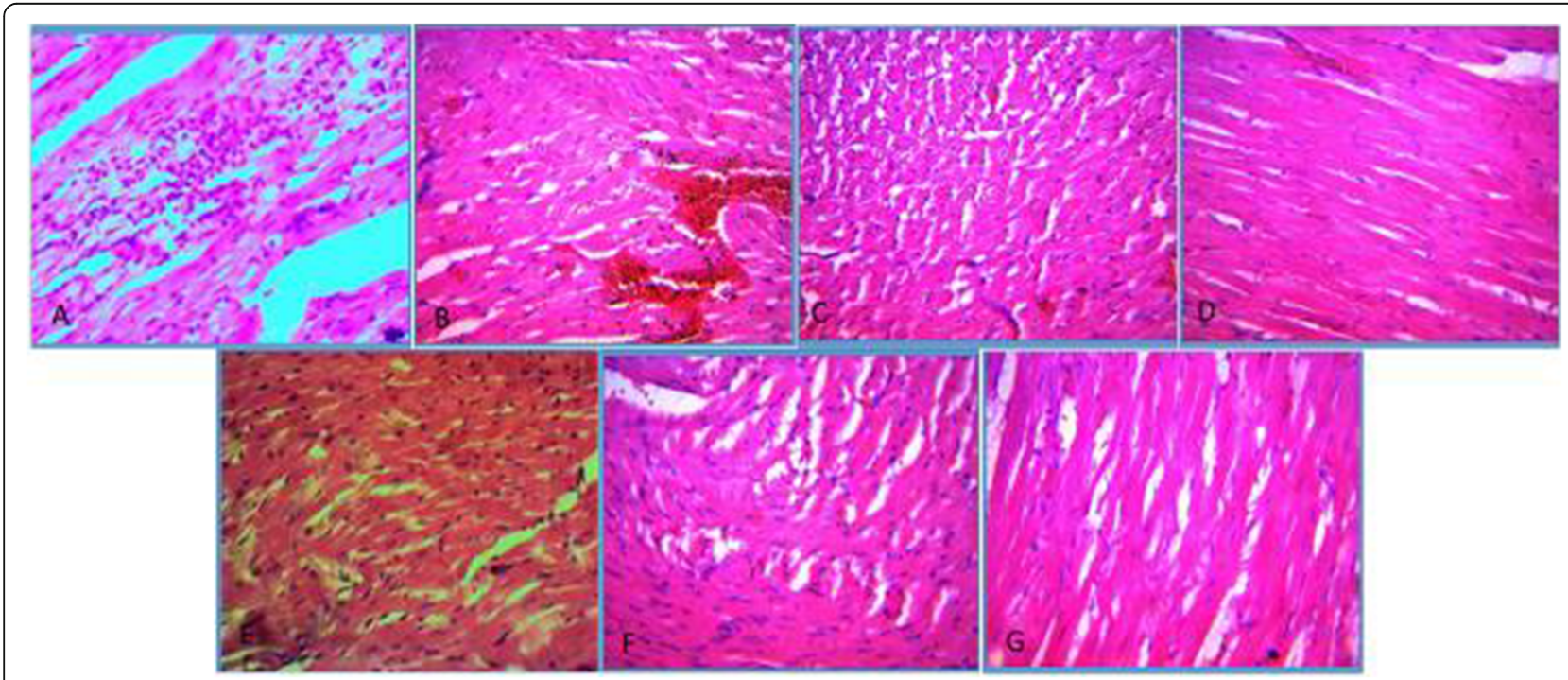

Fig. 4 Photomicrograph slides of rat heart (Hematoxylin and eosin staining, 100x magnification). A: Liver of Diabetic control; B: Liver of Obese diabetic control; C: Liver of Obese diabetic rats treated with 10\% Pleurotus tuber-regium; D: Liver of Obese diabetic rats treated with $20 \%$ Pleurotus tuber-regium; E: Liver of Drug control rats; F: Liver of Obese control rats; G Liver of Normal control rats 
Table 10 Effect of Pleurotus tuber-regium supplemented diet on the lipid profile in the liver of the rats

\begin{tabular}{llllll}
\hline $\begin{array}{l}\text { LIPID PROFILE/ } \\
\text { GROUPS }\end{array}$ & TC & TG & HDL & LDL & VLDL \\
\hline $\boldsymbol{A}$ (Normal diet) & $64.33 \pm 4.04^{\mathrm{a}}$ & $47.67 \pm 13.65^{\mathrm{a}}$ & $32.67 \pm 4.93^{\mathrm{b}}$ & $22.13 \pm 1.50^{\mathrm{a}}$ & $9.53 \pm 2.73^{\mathrm{ab}}$ \\
B (obese; HFD control) & $76.67 \pm 3.06^{\mathrm{c}}$ & $57.67 \pm 1.53^{\mathrm{bc}}$ & $25.22 \pm 4.36^{\mathrm{a}}$ & $33.33 \pm 1.51^{\mathrm{ab}}$ & $16.33 \pm 0.31^{\mathrm{bc}}$ \\
C (Diabetic untreated) & $71.64 \pm 2.0^{\mathrm{b}}$ & $51.67 \pm 6.66^{\mathrm{ab}}$ & $25.67 \pm 5.69^{\mathrm{a}}$ & $38.97 \pm 5.02^{\mathrm{b}}$ & $14.33 \pm 1.33^{\mathrm{b}}$ \\
$\boldsymbol{D}$ (Obese diabetic untreated) & $78.67 \pm 3.02^{\mathrm{c}}$ & $54.33 \pm 5.86^{\mathrm{b}}$ & $25.33 \pm 7.57^{\mathrm{a}}$ & $32.47 \pm 1.67^{\mathrm{ab}}$ & $18.87 \pm 1.17^{\mathrm{c}}$ \\
E(10\%Pleurotustuber-regium supplemented diet) & $67.45 \pm 8.19^{\mathrm{ab}}$ & $49.33 \pm 7.37^{\mathrm{ab}}$ & $36.98 \pm 7.20^{\mathrm{b}}$ & $23.13 \pm 2.93^{\mathrm{a}}$ & $7.86 \pm 1.47^{\mathrm{a}}$ \\
F(20\%Pleurotustuber-regium supplemented diet) & $65.67 \pm 12.34^{\mathrm{a}}$ & $46.67 \pm 7.64^{\mathrm{a}}$ & $35.14 \pm 9.64^{\mathrm{b}}$ & $23.33 \pm 3.22^{\mathrm{a}}$ & $7.33 \pm 1.53^{\mathrm{a}}$ \\
G (Atenonol + Glibenclamide) & $69.67 \pm 0.58^{\mathrm{ab}}$ & $51.34 \pm 2.0^{\mathrm{ab}}$ & $34.86 \pm 2.07^{\mathrm{b}}$ & $30.27 \pm 1.82^{\mathrm{ab}}$ & $10.40 \pm 240^{\mathrm{ab}}$
\end{tabular}

Results are expressed as mean $\pm S D, n=5$. Mean with the same alphabet within a column are not significantly different at $P<0.05$. KEY

TC = Total Cholesterol, TG = Triglyceride, HDL = High Density Lipoprotein, LDL = Low Density Lipoprotein, VLDL = Very Low Density Lipoprotein.

other groups can be attributed to the antihyperlipidaemic properties of the mushroom which agrees with the findings of Jeong et al., [26].

Results from the haematological analysis indicate that anaemia is a pathophysiology associated with obesity and diabetes mellitus as the obese and obesediabetic rats had lowered RBC, PCV and HB values when compared to normal control group and Pleurotus tuber-regium treatment groups. Also, there were significantly increased PLT values of these groups with the inclusion diabetic control groups when compared with normal control and 10\% Pleurotus tuber-regium group. The results are consistent with that of Akindele et al., [58], who reported that in diabetes mellitus, there is development of anaemia, particularly, the hypochromic type, due to fall in the iron content of the body resulting from oxidative stress associated with the condition. $10 \%$ of the mushroom diet restored the values of these parameters to normal in the obese diabetic rats, which suggests that Pleurotus tuber-regium has an anti-anaemic activity. The decrease in the neutrophils and monocytes of Pleurotus

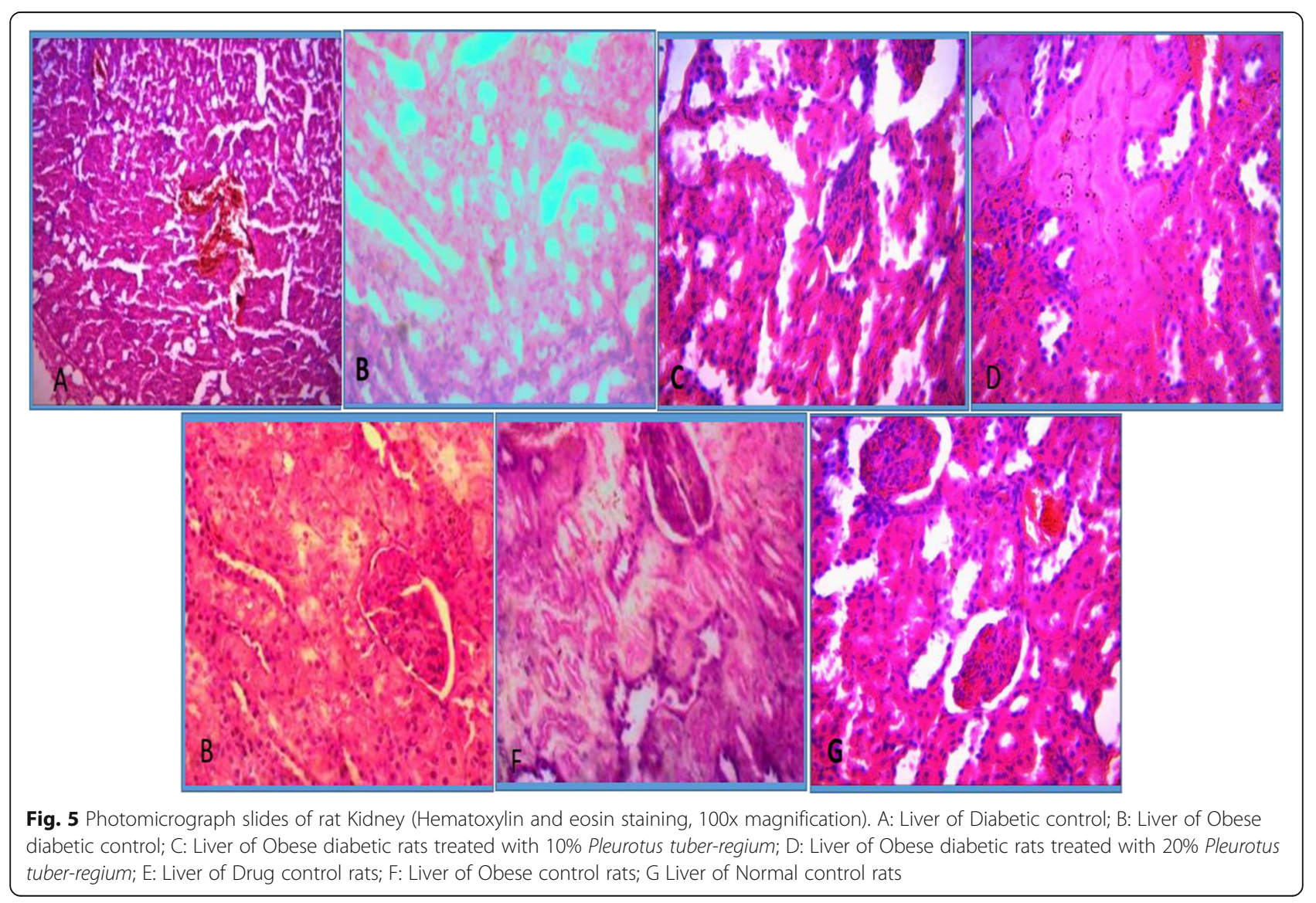




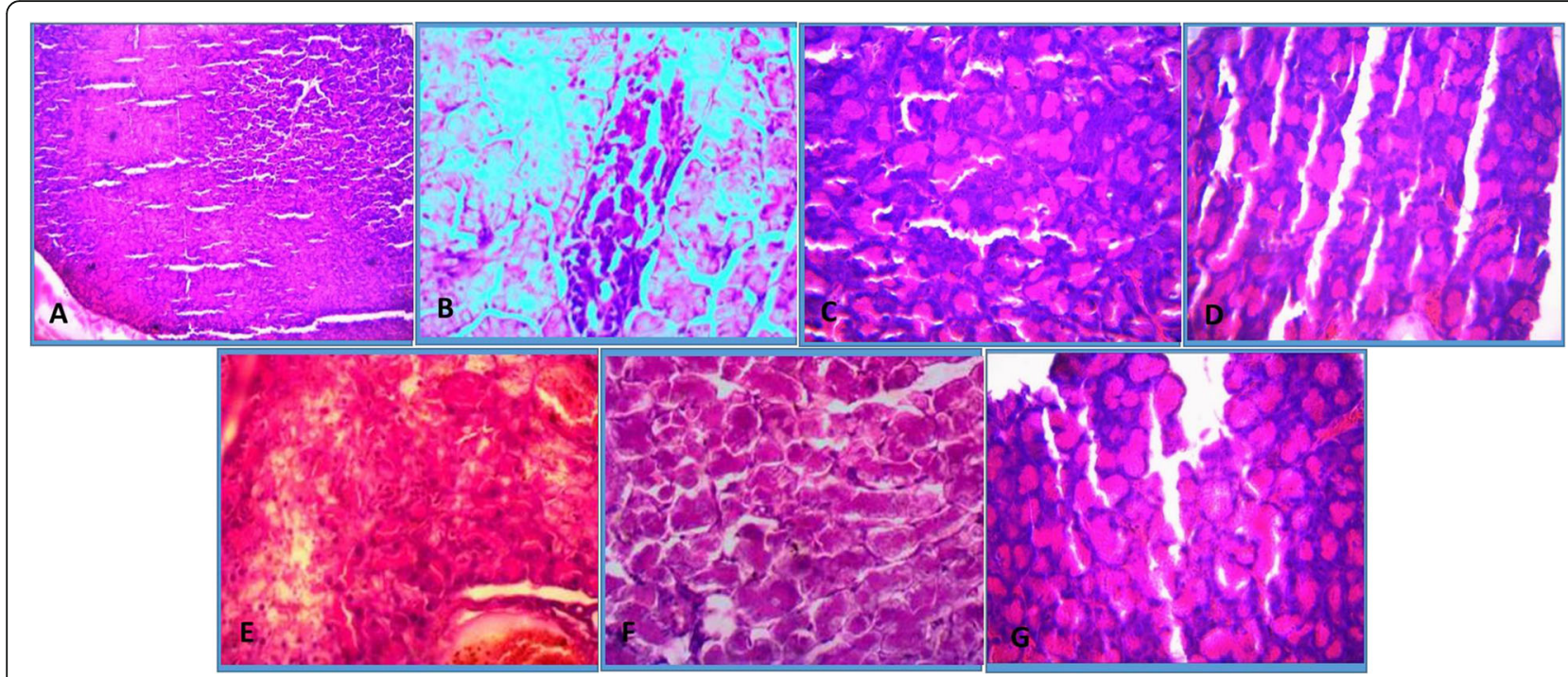

Fig. 6 Photomicrograph slides of rat Pancreas (Hematoxylin and eosin staining, 100x magnification). A: Liver of Diabetic control; B: Liver of Obese diabetic control; C: Liver of Obese diabetic rats treated with 10\% Pleurotus tuber-regium; D: Liver of Obese diabetic rats treated with 20\% Pleurotus tuber-regium; E: Liver of Drug control rats; F: Liver of Obese control rats; G Liver of Normal control rats

tuber-regium treatment groups suggests that it might modulate the inflammatory cells and limit inflammation [59].

High-fat diets (HFD) increase plasma glucose levels and decrease insulin secretion in healthy individuals $[60,61]$. A major feature of insulin resistance that accompanies diabetes includes dyslipidaemia, characterized by high triglyceride, low high-density lipoprotein (HDL), and high low-density lipoprotein (LDL) serum levels [62]. Pleurotus mushrooms had been recommended as a natural cholesterol lowering substance within the human diet [63]. A significant reduction in the ratio of High density lipoprotein to Low density lipoprotein of treatment group compared with the diabetic control rats is suggestive of the ability of the mushroom to reduce atherosclerosis, a complication of diabetes. The elevated TC, TG, low density lipoprotein cholesterol (LDL-C), and very low density lipoprotein cholesterol (VLDL-C) accompanied by decreased HDL cholesterol (HDL-C) observed in the untreated diabetic group agree with existing literature report, that the development of diabetes mellitus is usually accompanied by marked increase in blood cholesterol, triglycerides, LDL-C, VLDL-C and a reduction in HDL-C [38]. The lowering of cholesterol, triglycerides, LDL-C and VLDL$\mathrm{C}$ and increase in HDL-C of the liver observed in the groups treated with mushroom supplemented diet is indicative of its hypolipidaemic properties in which saponins has been reported to possess the ability to reduce blood cholesterol consistent with the findings of Kim et al., [64] on Pleurotus eryngii.
Pancreatic islet cells of the group treated with the Pleurotus tuber-regium supplemented diet appears normal which depicts that the mushroom has the ability to regenerate islet cells due the presence of some antioxidant compound such as flavonoids. Histology of the heart, kidney, liver and pancreas sections shows several damages caused as an effect of diabetes and obesity. The liver sections of Pleurotus tuber-regium treatment groups revealed almost no morphological difference from control. However, there were damages such as hyperplasia and degeneration of hepatocytes in the other groups. Histology of the heart sections of Pleurotus tuber-regium treatment groups shows no difference from the control, but there is myofibre degeneration, congestion and haemorrhage into the interstiitum, myofibre congestion of the coronary vessel in the obese groups, diabetic control as well as the obese diabetic control respectively. Histology of the kidney sections of Pleurotus tuber-regium treatment groups showed mild interstitial congestion at the renal cortex and few tubular degeneration and necrosis when compared to the control. The photomicrograph revealed severe tubular degeneration and necrosis of the glomeruli in the diabetic control rats as well as the obese rats. This may be attributed to increased diuresis and renal hypertrophy. The histology of the pancreas sections of $P$. tuber-regium treatment groups showed no difference with the acinar cells appearing to be normal when compared to the control. Pancreatic islet cells of the group treated with the P. tuberregium supplemented diet appears normal which 
depicts that the mushroom has the ability to regenerate islet cells.

\section{Conclusion}

The results obtained from this research show that supplementation of $P$. tuber-regium in food is able to attenuate the obese-diabetes-induced adverse effects by reducing blood glucose and reverting dyslipidaemia. Potent antihyperglycaemic and hypolipidaemic properties of polysaccharides may be attributed to reducing the lipid profile and since edible mushrooms are underutilized, it could be a source of dietary fibre especially in managing obesity and type II DM.

\section{Abbreviations}

P.T: Pleurotus tuber-regium; HFD: High fat diet; LDL-C: low density lipoprotein cholesterol; (VLDL-C) VLDL-C: very low density lipoprotein cholesterol; HDLC: high density lipoprotein cholesterol; T2DM : type 2 diabetes; A : Atenonol.; G : Glibenclamide.; UI-ACUREC: University of Ibadan Animal Care and Use of Research Ethics Committee; SD: Standard deviation

\section{Acknowledgements}

Not applicable.

\section{Authors' contributions}

Akindele Oluwatosin Adeyi: Methodology, Supervision, Writing - review \& editing.. Folasade Ajoke Adams: Project administration, Writing - original draft. Clementina Oyinkansola Adenipekun: Conceptualization, Supervision. The authors read and approved the final manuscript.

\section{Funding}

The research did not receive any specific grant from funding agencies in the public, commercial or not- for- profit sectors.

\section{Declarations}

Availability of data and material

All data have been presented here.

\section{Ethics approval and consent to participate}

All methods are performed in accordance with the relevant guidelines and regulations. Ethical approval was obtained, and the experimental protocols conform to ethical guidelines of Animal Care and Use of Research Ethics Committee (UI-ACUREC), University of Ibadan, Ibadan, Oyo State, Nigeria.

\section{Consent for publication}

Not applicable.

\section{Competing interests}

The authors declare that they have no competing interest.

\section{Competing interests}

The authors declare no conflict of interest.

\section{Author details}

${ }^{1}$ Animal Physiology Unit, Department of Zoology, University of Ibadan, Ibadan, Nigeria. ${ }^{2}$ Department of Botany, University of Ibadan, Ibadan, Nigeria.

Received: 12 July 2021 Accepted: 25 October 2021

Published online: 10 November 2021

\section{References}

1. Farzaei F, Morovati MR, Farjadmand F, Farzaei MH. A mechanistic review on medicinal plants used for diabetes mellitus in traditional persian medicine. Journal of Evidence-Based Complementary and Alternative Medicine. 2017; 22(4):944-55. https://doi.org/10.1177/2156587216686461.
2. Oyebode $\mathrm{OA}$, Erukainure $\mathrm{OL}$, Chukwuma Cl, Ibeji CU, Koorbanally NA, Islam MS. Boerhaavia diffusa in hibits key enzymes linked to type 2 diabetes in vitro and in silico; and modulates abdominal glucose absorption and muscle glucose uptake ex vivo. Biomed Pharmacother. 2018;106:1116-25. https://doi.org/10.1016/j.biopha.2018.07.053.

3. Chukwuma $\mathrm{Cl}$, Islam MS, Amonsou EO. A comparative study on the physicochemical, antioxidative, anti-hyperglycaemic and anti-lipidemic properties of amadumbe (Colocasia esculenta) and okra (Abelmoschus esculentus) mucilage. J Food Biochem. 2018;42(5):e12601. https://doi.org/1 $0.1111 /$ jfbc. 12601

4. Goossens $\mathrm{GH}$. The role of adipose tissue dysfunction in the pathogenesis of obesity-related insulin resistance. Physiology and Behaviour. 2008;94(2):20818. https://doi.org/10.1016/.jphysbeh.2007.10.010.

5. International Diabetes Federation, (IDF), 2015. Diabetes Atlas, 7th edition. Retrieved from tesat las.org/resources/2015-atlas.html

6. International Diabetes Federation. IDF diabetes atlas (8th ed.). Retrieved from tesat las.org/resources/2017-atlas.html

7. World Health Organization (WHO), Global Report on Diabetes, Geneva, Switzerland;2016.

8. Guariguata L, Whiting DR, Hambleton I, Beagley J, Linnenkamp U, Shaw JE. IDF Diabetes Atlas: Global estimates of diabetes prevalence for 2013 and projections for 2035. Diabetes Research and Clinical practice. 2014;103:137-49.

9. World Health Organisation (WHO) 2020. https://www.who.int/nutgrowthdb/ publications/overweight_obesity/en/\#: :text=The\%20worldwide\%20preva lence\%20of\%20childhood,'60\%20million\%2C\%20in\%202020.

10. Mbanya JC, Motala AA, Sabgw E. Diabetes in sub-saharan Africa. Lancet. 2010:375(22):54-6.

11. Muszynska B, Sulkowska-Ziaja K, Ekiert H. Phenolic acids in selected edible basidiomycota species: Armillaria mellea, boletus badius, boletus edulis, Cantharellus cibarius, Lactarius deliciosus and Pleurotus ostreatus. Journal of Acta Scientarium Polonorum Hortorum Cultus. 2013;12:107-16.

12. Abdullah N, Ismail SM, Aminudin N, Shuib AS, Lau BF. Evaluation of selected culinary-medicinal mushrooms for antioxidant and ACE inhibitory activities. Evid Based Complement Alternat Med. 2012;6(23):6853-9. https://doi.org/1 $0.1155 / 2012 / 464238$

13. Asemota UK, Etim VA, Okereke OE, Abubakar S, Ogbadu GH. Mushroom biotechnology in Nigeria-implications for food security, environment and public health, a review. Journal of Advances in Biology and Biotechnology. 2015;2(2):96-108. https://doi.org/10.9734/JABB/2015/14197.

14. Gbolagade J, Sobowale A, Adeyoye D. Optimization of sub- merged culture conditions for biomass production in Pleurotus florida, a Nigerian edible fungus. Afr J Biotechnol. 2006;5(16):1464-9.

15. Ijeh II, Okwujiako IA, Nwosu PC, Nnodim HI. Phytochemical composition of Pleurotus tuber regium and effect of its dietary incorporation on body /organ weights and serum triacylglycerol's in albino mice. Journal of Medicinal Plants Research. 2009;3(11):939-43.

16. Sanchez C. Cultivation of Pleurotus ostreatus and other edible mushrooms. Appl Microbiol Biotechnol. 2010;85(5):1321-37. https:/doi.org/10.1007/s00253-009-2343-7.

17. Barros L, Venturini BA, Baptista P, Estevinho LM, Ferreira IC. Chemical composition and biological properties of Portuguese wild mushrooms: a comprehensive study. Journal of Agricultural Food Chemistry. 2008:56(10): 3856-62. https://doi.org/10.1021/jf8003114.

18. Turkoglu A, Duru EM, Mercan N. Antioxidant and antimicrobial activity of Russula delica Fr: an edible wild mushroom. Eurasian Journal of Analytical Chemistry. 2007:2:54-67.

19. Soares AA, de Souza CGM, Daniel FM, Ferrari GP, da Costa SMG, Peralta RM. Antioxidant activity and total phenolic content of Agaricus brasiliensis (Agaricus blazei Murril) in two stages of maturity. Food Chem. 2009;112(4): 775-81. https://doi.org/10.1016/j.foodchem.2008.05.117.

20. Afrisham, R., Aberomand, M., Ghaffari, M. A., Siahpoosh, A., \& Jamalan, M. Inhibitory Effect of Heracleum persicum and Ziziphus jujuba on Activity of Alpha-Amylase. Journal of Botany, 2015, Inhibitory Effect ofHeracleum persicumandZiziphus jujubaon Activity of Alpha-Amylase.

21. Patel $Y$, Naraian $R$, Singh VK. Medicinal properties of Pleurotus species (oyster mushroom): a review. World Journal of Fungal and Plant Biology. 2012;3(1):01-1.

22. Adejumo TO, Awosanya OB. Proximate and mineral composition of four edible mushroom species from South Western Nigeria. Afr J Biotechnol. 2005;4(10):1084-8

23. Barros L, Baptista P, Estevinho LM, Ferreira ICFR. Bioactive properties of the medicinal mushroom Leucopaxillus giganteus mycelium obtained in the 
presence of different nitrogen sources. Food Chem. 2007;105(1):179-86. https://doi.org/10.1016/j.foodchem.2007.03.063.

24. Ferreira ICFR, Barros L, Abreu RMV. Antioxidants in wild mushrooms. Curr Med Chem. 2009;16(12):1543-60. https://doi.org/10.2174/092 986709787909587.

25. Heleno SA, Martins A, Queiroz MJRP, Ferreira ICFR. Bioactivity of phenolic acids: metabolites versus parent compounds: a review. Food Chem. 2015; 173:501-13. https://doi.org/10.1016/j.foodchem.2014.10.057.

26. Jeong SC, Jeong YT, Yang BK, Islam R, Koyyalamudi SR, Pang G, et al. White button mushroom (Agaricus bisporus) lowers blood glucose and cholesterol levels in diabetic and hypercholesterolemic rats. Nutrition Research journal. 2010;30(1):49-56. https://doi.org/10.1016/j.nutres.2009.12.003.

27. Sun JE, Ao ZH, Lu ZM, Xu HY, Zhang XM, Dou WF, et al. Antihyperglycaemic and antilipid peroxidative effects of dry matter of culture broth of Inonotus obliquus in submerged culture on normal and alloxan-diabetes mice. Journal of Ethno pharmacology. 2008;118(1):7-13. https://doi.org/10.1016/j.jep.2008.02.030.

28. Silva DD, Rapior S, Hyde KD, Bahkali AH. Medicinal mushrooms in prevention and control of diabetes mellitus. Fungal Divers. 2012;56(1):1-29. https://doi.org/10.1007/s13225-012-0187-4

29. Andrew G, Mirjan S, Juru P. Cultivation techniques and medicinal Pleurotus species. Food Technological Biotechnology. 2007:45(3):238-49.

30. Alobo AP. Proximate composition and functional properties of Pleurotus tuber regium sclerotia flour and protein concentrate. Plant Foods for HumanNutrition. 2003;58(3):1-9. https://doi.org/10.1023/B:QUAL.0000040348.97597.23.

31. Chen AW, Huang N. Production of tuber-like sclerotia of medicinal value by Pleurotus tuberregium (Fr.) Sing. (Agaricomycetideae), International Journal of Medicinal Mushrooms. 2004;5:313-9.

32. Badalyan SM, Isikhuemhen SO, Gharibyan GN. Antagonistic/antifungal activities of medicinal mushroom Pleurotus tuberregium (Fr.) Sing. (Agaricomy- cetideae) against selected filamentous fungi, International Journal of Medicinal Mushroom. 2008;10:155-62.

33. Ezeronye OU, Okwujiako DAS, Onumajuru ICIA. Antibacterial effect of crude polysaccharide extracts from sclerotium and fruit-body (sporophore) of Pleurotus tuber-regium (fries) singer on some clinical isolates. International Journal of Molecular Medicine and Advance Sciences. 2005;1:202-5.

34. Isikhuemhen O, Anoliefo G, Oghale O. Bioremediation of crude oil polluted soil by the white rot fungus Pleurotus tuberregium (Fr.) Sing. Environmental Science and Pollution Research. 2003;10:108-12.

35. Adenipekun CO. Bioremediation of engine-oil polluted soil by Pleurotus tuber-regium singer, a Nigerian white-rot fungus. Afr J Biotechnol. 2008;7(1): 55-8.

36. Lawal MO, Aderolu AZ, Aarode OO. Growth and economic performance of Nile Tilapia, Oreochromis niloticus (L.) fingerlings fed diets containing graded levels of sclerotium. Aquacultue, Aquarium, Conservation and LegislationInternational Journal of Bioflux Society. 2013;6:180-7.

37. Onuekwuzu IM, Chidinma IC, Chigozie IJ. Anti-diabetic effect of a flavonoid and Sitosterol - rich aqueous extract of Pleurotus tuberregium Sclerotia in Alloxan-induced diabetic rabbits. Endocr Metab Immune Disord Drug Targets. 2019;19(8):1148-56. https://doi.org/10.2174/1871530319666190206213843.

38. Huang H-Y, Korivi M, Chaing Y-Y, Chien T-Y, Tsai Y-C. Pleurotus tuber-regium Polysaccharides Attenuate Hyperglycaemic and Oxidative Stress in Experimental Diabetic Rats. Hindawi Publishing Corporation Evidence-Based Complementary and Alternative Medicine. 2012; Article ID 856381, 8 pages. https://doi.org/10.1155/2012/856381.

39. Hui-Yu H, Mallikarjuna $K$, Ying-Ying $C$, Hu-Ting $Y$, Ying-Chieh T. Effect of Pleurotus tuber-regium polysaccharides supplementatation on the progression of complications in obese-diabetic rats. Chin J Physiol. 2014; 57(4):198-208. https://doi.org/10.4077/CJP.2014.BAC245.

40. ljeh II, Okwujiako IA, Nwosu PC, Nnodim HI. Phytochemical composition of Pleurotus tuber regium and effect of its dietary incorporation on body /organ weights and serum triacylglycerol's in albino mice. Journal of Medicinal Plants Research. 2009:3(11):939-43.

41. Tyler V. Phytomedicines in Western Europe: their potential impact on herbal medicine in the United States Herbalgram; 1994; 30: 24-30.

42. Harborne JB. Phytochemical methods: a guide to modern techniques of plant analysis. Chapman and Hall Ltd, London. 1973;278. https://doi.org/10.1 007/978-94-009-5921-7_1.

43. Brunner JH. Direct spectrophotometer determination of saponins. Anal Chem. 1984;34:1314-26.

44. AOAC. Official method of analysis. $18^{\text {th }}$ edition, Revision 3, Association of Official Analytical Chemists, Washington D. C. 2010.
45. Rowett HGQ. Dissection guides: III the rat paperback. New york: Rinehart and Company; 1977.

46. Cheesbrough.District laboratory practice in tropical countries: Haematological test ( $2^{\text {nd }}$ edition) Cambrigde low price editions, 2004. 263347.

47. Friedewald WT, Levy RI, Fredrickson DS. Estimation of concentration of low density lipoprotein cholesterol. Clin Chem. 1972;18(6):499-502. https://doi. org/10.1093/clinchem/18.6.499.

48. Francis G, Kerem Z, Makkar HP, Becker K. The biological action of saponins in animal systems: a review. Br J Nutr. 2002;88(6):587-605. https://doi.org/1 0.1079/BJN2002725

49. Chang, S. T., and Miles, G. Edible mushrooms and their cultivation. CRC Press, Inc., 1989. Boca Raton, FL.

50. Akindahunsi AA, Oyetayo FL. Nutrient and anti-nutrient distribution of edible mushroom, Pleurotus tuber regium (fries) singer. Leben SmittelWissenschaft and Technologie. 2006;39(950):548-53. https://doi.org/10.1016/ j.lwt.2005.04.005

51. FAO (Food and Agriculture Organization). Protein quality evaluation. 1991. Food and Agricultural Organization of the United Nations: Rome.

52. Cheskin L, Davis LM, Lipsky LM, Mitola AH, Lycan T, Mitchell V, et al. Lack of energy compensation over 4 days when white button mushrooms are substituted for beef. Appetite. 2008;51(1):50-7. https://doi.org/10.1016/j.a ppet.2007.11.007.

53. Lamidi WA, Murtadha MA, Ojo DO. Effect of planting locations on the proximate compositions of Moringa oleifera leaves: J. Appl Sci Environ Manage. 2017;27(12):331-8. https://doi.org/10.4314/jasem.v21i2.14.

54. Lo HC, Tu ST, Lin KC, Lin SC. The anti-hyperglycaemic activity of the fruiting body of Cordyceps in diabetic rats induced by nicotinamide and streptozotocin. Life Science. 2004;74(23):2897-908. https://doi.org/10.1016/j. Ifs.2003.11.003.

55. Srinivasan K, Ramarao P. Animal models in type 2 diabetes research: an overview. Indian J Med Res. 2007;125(3):451-72.

56. Uedeme-Naa B, George AD. The influence of Moringa Oleifera leaf powder on Organosomatic index. Condition Factor and Glucose Profile of Clarias Gariepinus. 2019;6(3):31-6.

57. Thomas R, Kanso A, Sedor JR. Chronic kidney disease and its complications. Primary Care. 2008;35(2):329-44. https://doi.org/10.1016/j.pop.2008.01.008.

58. Akindele OA, Babatunde Al, Chinedu FM, Samuel OA, Oluwasola CA, Oluseyi AA. Rat model of food induced non-obsessed Type-2 diabetes mellitus; comparative pathophysiology and histopathology. International Journal of Physiology. 2012;4(1):51-8.

59. Okolo, K. O., Siminialayi, I. M., \& Orisakwe, O. E. . Protective effects of Pleurotus tuber-regium on carbon-tetrachloride induced testicular injury in Sprague Dawley rats. Front Pharmacol, 2016; 7, 480, Protective Effects of Pleurotus tuber-regium on Carbon- Tetrachloride Induced Testicular Injury in Sprague Dawley Rats, DOI: https://doi.org/10.3389/fphar.2016.00480.

60. Numao S, Kawano H, Endo N, Yamada Y, Konishi M, Takahashi M, et al. Short-term low carbohydrate/high-fat diet intake increases postprandial plasma glucose and glucagon-like peptide-1 levels during an oral glucose tolerance test in healthy men. Eur J Clin Nutr. 2012;66(8):926-31. https://doi. org/10.1038/ejcn.2012.58.

61. Numao S, Kawano H, Endo N, Yamada Y, Konishi M, Takahashi M, et al. Effects of a single bout of aerobic exercise on short-term low-carbohydrate/ high-fat intake-induced postprandial glucose metabolism during an oral glucose tolerance test. Metabolism. 2013;62(10):1406-15. https://doi.org/10.1 016/j.metabol.2013.05.005.

62. Yang JY, Moon E, Nam SH, Friedman M. Antidiabetic effects of rice hull smoke extract on glucose-regulating mechanism in type 2 diabetic mice. J Agric Food Chem. 2012;60(30):7442-9. https://doi.org/10.1021/jf3017749.

63. Gunde-Cimerman, N. Medicinal value of the genus Pleurotus (Fr.) P. Karst. (Agaricales S.I. Basidiomycetes). International Journal of Medicinal Mushrooms. 1999, 1: 69-80.

64. Kim JI, Kang MJ, Im J, Seo YJ, Lee YM, Song JH, et al. Effect of king oyster mushroom (Pleurotus eryngii) on insulin resistance and Dyslipidaemia in diabetic mice. Food Science and biotechnology journal. 2010;19(1):239-42. https://doi.org/10.1007/s10068-010-0033-y.

\section{Publisher's Note}

Springer Nature remains neutral with regard to jurisdictional claims in published maps and institutional affiliations. 